\title{
Application of Chitosan from Corbula Faba Hinds shells as a Bio-Coagulant for River Water Treatment
}

\author{
Kindriari Nurma Wahyusi*, Ardika Nurmawati, and Lucky Indrati Utami \\ Department of Chemical Engineering, Faculty of Engineering, Universitas Pembangunan Nasional (UPN) "Veteran" Jawa Timur, \\ Surabaya, Indonesia
}

\begin{abstract}
Corbula faba Hinds or white mussel is one of the marine organisms easily found around Sidoarjo, East Java, Indonesia. The main component of its shell is chitin that can be derivate to chitosan. Chitosan is widely used especially in the water treatment process as a coagulant due to its biocompatibility and biodegradability. In this study, chitosan produced from white mussel shells was used as a coagulant for treated Surabaya River water. The initial value of TSS in the sample water was $373.0 \mathrm{mg} / \mathrm{L}$ whereas TDS was $59.5 \mathrm{mg} / \mathrm{L}$. The rapid mixing condition, such as speed and time, influenced the result of solids removal. Higher speed and longer time mixing would give better performance of flocs formation, but the flocks would be unstable after reach some points of conditions. The optimum mixing condition was obtained when using140 rpm on speed for 4 minutes with TSS removal up to $94.96 \%$ and TDS removal up to $23.32 \%$.
\end{abstract}

Keywords: Chitosan, Corbula faba Hinds, Bio-coagulant

\section{Introduction}

Indonesia is an archipelagic country with various kinds of marine life. With a comparison of the sea area reaching two-thirds of its land, Indonesia has the second-longest coastline in the world reaches 104 thousand $\mathrm{km}$ [1]. One of the marine lives that lives on the beach is white mussel (Corbula faba Hinds) which can be found especially on Sidoarjo, East Java, Indonesia. The production of white mussel from that area reach up to 8.6 million $\mathrm{kg}$ each year [2]. Along with that high production, it is also accompanied by a lot of shell waste that has not been processed optimally. Shell waste was usually thrown away into water bodies or landfills that caused environmental issues such as polluted the water surface and coastal fisheries, sanitation problems, and air pollution due to microbial decomposition that occurs on the waste [3]. So, they need more attention to be processed to minimize the problems.

One of the components in the mussel shell is chitin as the fibrous support of the inorganic mineral phase. Besides mussels, chitin is also easily found in the crustacean shells like shrimp and crab, squid cartilage, insect outer cover, or yeast and fungi cell walls. Generally, some of crustacean consist of several components such as protein $(30-40 \%)$, calcium carbonate and calcium phosphate $(30-50 \%)$, and chitin $(20-30 \%)$. While in mussel shell was discovered $51.62 \%$ mineral content and $21.32 \%$ chitin [4].

Chitin is a crystalline polysaccharide with a linear chain structure and high molecular weight. Ideally, chitosan is composed of $\beta$-(1-4)-2-acetamido-2-deoxy-Dglucopyranose repeating units which the amine groups are thoroughly acetylated. The primer chitin derivation is chitosan that obtained by deacetylated the amine groups. The chemical structure of chitosan is structured by linear chain of $\beta$-(1-4)-2-amino-2-deoxy-D-glucopyranose repeating units where the main repeating unit is glucosamine. Chitin and chitosan are crystalline, but chitosan have a longer distance between chains in the same sheet. This condition occurs due to the removal of the $\mathrm{N}$-acetyl groups during the conversion from chitin to chitosan where adjacent chains hold together through $\mathrm{C}$ (2) $\mathrm{N}-\mathrm{H} \cdots \mathrm{O}==\mathrm{C}$ hydrogen bonds. In chitosan formation, can be found $\mathrm{N}$-acetylglucosamine and $\mathrm{N}$-glucosamine copolymer units that spread disordered or block in the chain $[5,6]$. One of the chitosan characteristics is the degree of deacetylation (DD) that influenced its mechanical and other properties. This parameter shows the molar percentage of glucosamine monomeric units. DD of chitosan range from $0 \%$ (pure chitin form) to $100 \%$ (pure chitosan or fully deacetylated chitin) [7]. Chitosan is already widely used whether in pharmaceutical or industrial processes due to its biocompatibility, nontoxicity, biodegradability, antibacterial activity, noncorrosivity, and safety $[8,9]$.

Jagir river, one of the river flows over the lowland part of Surabaya, Indonesia, has been polluted by many human activities like domestic, agricultural, and industrial activities. Those pollutants could reduce water quality and cause damage to the aquatic ecosystem [10]. For

\footnotetext{
* Corresponding author : kindrinurma@gmail.com
} 
preliminary steps, the use of coagulation and flocculation are needed to remove the solids.

There is a various range of solids type in the waste water depending on the size particles. Total suspended solids (TSS) defined as a particle with a size of more than $2 \mu \mathrm{m}$. Several particles which included as TSS are minerals in clay, dead and living plankton, and humic substance. A high concentration of TSS materials would block the light penetration and shallow the water bodies that can be decrease the water quality [11]. In a filtration process, TSS materials would retain on the filter and dried at a specific temperature $\left(105^{\circ} \mathrm{C}\right)$. Whereas total dissolved solids (TDS) have particle size less than $2 \mu \mathrm{m}$ or can pass through the filter. Typically, the particle size ranged from 0.001 to $1 \mu \mathrm{m}$. TDS consists of a several materials like inorganic salts $\left(\mathrm{Na}^{+}, \mathrm{Mg}^{2+}, \mathrm{Ca}^{2+}, \mathrm{SO}_{4}{ }^{2-}\right.$, etc. $)$ and dissolved organic matter $[12,13]$.

Coagulation and flocculation are consecutive steps process that will destabilize the forces of suspended particles and allowed the particle to collide along with the growth of floc. In polluted water, the surface of colloid particles was negatively charged and exhibit Brownian movement that resulted in particle repels and stable dispersion suspension. The addition of coagulants like metal salt with positive ion charged or catalytic polyelectrolyte would destabilize the particle and make a neutral charge in the water. Whereas flocculation process refers to the mechanism of the unstable particles when they collide toward each other driven by the hydraulic shear force with applied rapid mixing. The colloid will agglomerate and formed a floc [14].

Inorganic coagulants such as aluminium and iron were commercially used in water treatment due to their competitive costs, effectiveness, and handling. In contrary to their benefit, inorganic coagulants had many negative impacts not only to environment like sludge disposal problem but also to human health. It could causing constipation, convulsions, learning difficulty, memory loss, etc [15-17]. Natural coagulants like chitosan attracted more attention with their capability to produce larger flocs and faster settling velocity. Their sludge handling also easy since it is non-toxic and biodegradable [15]. Chitosan also has attractive characteristics where it could be act as coagulant and also flocculant. The cationic charge density of chitosan is high and it can work either in normal or high $\mathrm{pH}$ condition [18].

In coagulation and flocculation process, there are several mechanisms when using polymer coagulant like the bridge formation, adsorption of polymer and charge neutralization, depletion of flocculation, etc. When using chitosan as coagulant in coagulation and flocculation process, the mechanism often caused by the neutralization of charge, adsorption, precipitative coagulation, bridge formation, and electrostatic patch. Chitosan would neutralize the polluted water charge and destabilized it. The small colloid particle would become a large particle by bridge formation and also adsorbed dissolved organic substance by adsorption mechanism. The aggregates would be removed by filtration and sedimentation [18].

The coagulation process is influenced by many factors, whether from the water wanted to be treated or the operating conditions. The water characteristics, temperature, $\mathrm{pH}$, coagulant type and doses, and the mixing conditions were several concern factors. The classic coagulation process consists of three steps: rapid mixing, slow mixing, and sedimentation. When applied the rapid mixing, the coagulant was entered into the water at high speed stirred to obtain complete mixing. Slow mixing is to develop large flocs by increasing the contact between coagulating particles. The critical parameters for these two steps are the speed and duration of mixing. The last step was sedimentation which allowed the flocs to be settle [19].

The main focus of this study was to investigate the effect of rapid mixing condition, speed and time, in the coagulation process using chitosan from Corbula faba Hinds shells as natural coagulant in the removal of pollutants from Jagir River. The water analysis was conducted in TSS and TDS quality parameters.

\section{Material and method}

\subsection{Material}

In this study, the river water obtained from the Jagir River located in Surabaya, East Java, Indonesia. The sampling point was carried out in the sluice gates area around rain season in 2019.

Chitosan prepared from Corbula faba Hinds shell was obtained from Sidoarjo, East Java, Indonesia. After washing, the white mussel shell was dried by the sun for 4 days and followed by the oven at $100^{\circ} \mathrm{C}$. The dried shell then grounded, sieved, and stored in a dry place.

\subsection{Method}

\subsubsection{Chitosan Preparation}

The production process of chitosan from white mussel shells was performed by several steps: demineralization, deproteination, and deacetylation as shown in Fig. 1. The demineralization process begins with $1.5 \mathrm{M}$ chloric acid added into $100 \mathrm{~g}$ shell powder and heated at $60-70^{\circ} \mathrm{C}$ with $200 \mathrm{rpm}$ agitation. The sample was neutralized with demineralized water and dried using an oven with a temperature set at $90^{\circ} \mathrm{C}$ and 3 hours long.

The extraction of chitin was performed by reacted the demineralized powder with $\mathrm{NaOH} 3.5 \%$ while heated at $60-70^{\circ} \mathrm{C}$ for 1 hour while stirred using $200 \mathrm{rpm}$. The neutralized sample was then dried at $90^{\circ} \mathrm{C}$ for 3 hours.

The transformation of chitin to chitosan using deacetylation process where $\mathrm{NaOH} 60 \%$ added to the dried chitin sample while heated and mixed at $120^{\circ} \mathrm{C}$ for 4 hours and $200 \mathrm{rpm}$. The sample is filtered and neutralized with $\mathrm{H}_{2} \mathrm{O}$, then dried at $90^{\circ} \mathrm{C}$ for 3 hours. For characterization of chitosan, using a degree of deacetylation calculation. The chitosan produced from this process had a deacetylation degree of $65.08 \%$. 


\subsubsection{Coagulation process}

The coagulation process (Fig. 2) was tested using the jartest equipment. The beaker glass filled with $1000 \mathrm{~mL}$ sample water and added with chitosan coagulants. Those samples were stirred in two steps, rapid mixing and slow mixing. In this study, the velocity and the period were differed at various condition in the rapid mixing. The speed varied from 110 to $150 \mathrm{rpm}$ while the time from 1 to 5 minutes. Then followed with slow mixing with stirring speed at $40 \mathrm{rpm}$ in 10 minutes. The sample settled down in 1 hour and filtered. For knowing the effectiveness of the coagulant and the effect of the rapid mixing speed and time, TSS and TDS tests were carried out.

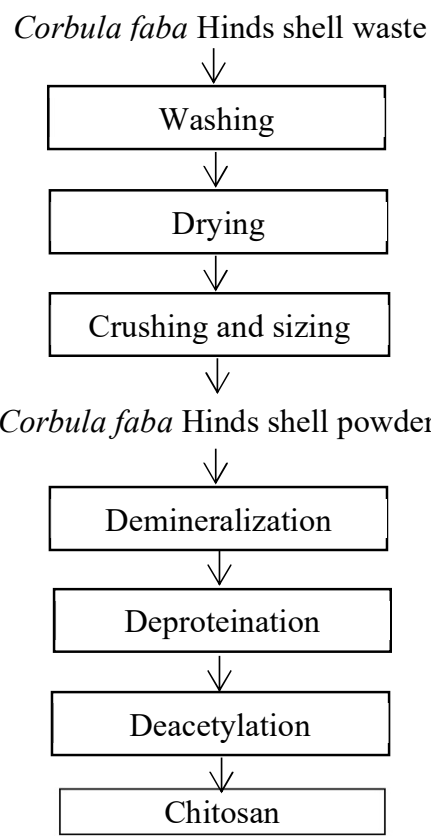

Fig. 1. Isolation process of chitosan from white mussel shells

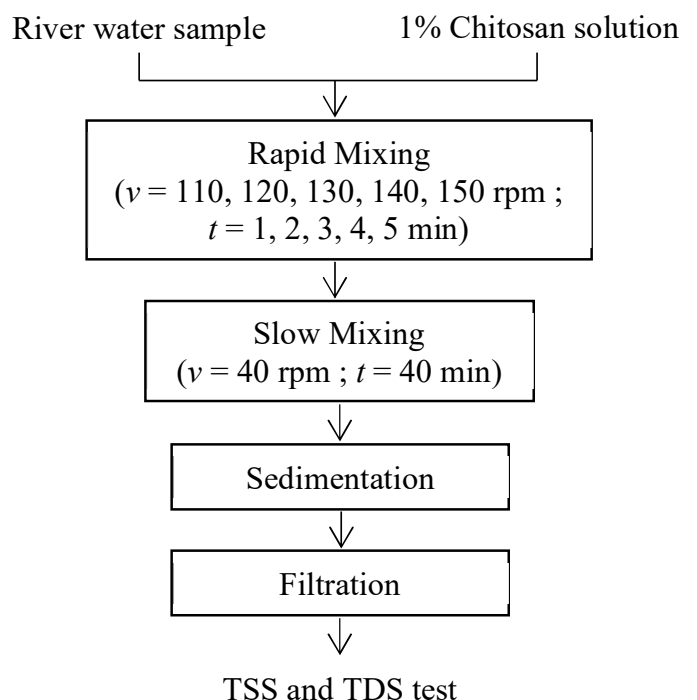

Fig. 2. Cogulation process in river water sample using chitosan

\section{Result and discussion}

The main purpose of coagulation using chitosan in this water treatment is to remove the solids. The initial value of TSS in the sample was $373.0 \mathrm{mg} / \mathrm{L}$ and for TDS was $59.5 \mathrm{mg} / \mathrm{L}$. In normal conditions, the particle in the polluted water or colloid would repel each other due to the electrostatic force around them greater than the attraction force between particles that made the colloidal particles were not easily separate from the water. The addition of chitosan as a natural coagulant would be destabilizing the colloid particles in the water. Due to the treatment of chitosan with acetic acid as solvent, chitosan became a soluble cationic polymer that produced protonated amine group. It made interaction between the chitosan and the negative charge pollutants in the water, like organics compounds, metal anions, and dyes. The coagulation mechanism by that charge neutralization and bridge formation where the small particles transferred into large aggregates. Also by an adsorption mechanism adsorb dissolved organic substances into aggregates [14,18,20]. With those mechanisms, the impurities can be settled down and easily removed. Besides the use of coagulant, the coagulation performance is strongly affected by mixing conditions, like mixing speed and period.

The percentage of TSS and TDS removal in the mixture depended on mixing speed after the coagulant added. After the predetermined rapid mixing, the agitation was lowered to a slow mixing speed $(40 \mathrm{rpm})$ in order to form flocs. The mixing process would also decrease the electrostatic force between particles and help the formation of flocs.

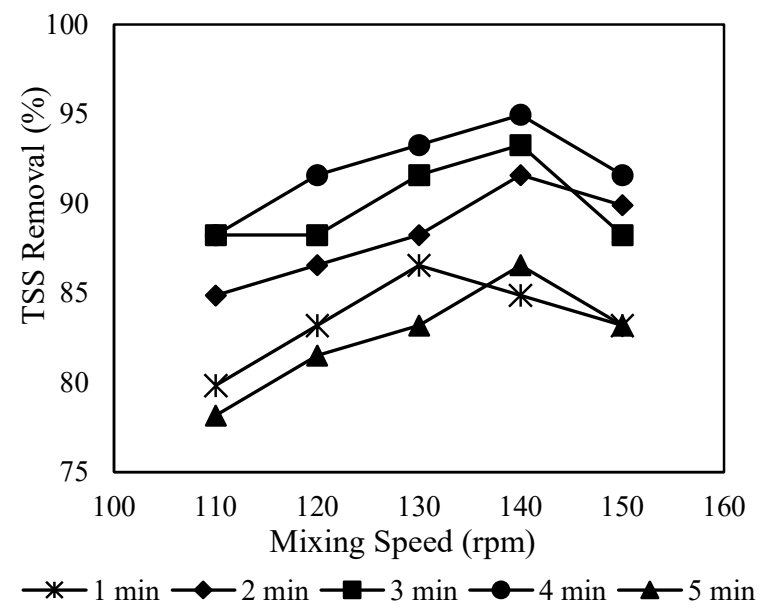

Fig. 3. The effect of mixing speed in chitosan addition for TSS removal

The higher mixing speed applied in the mixture, the removal of TSS will be increased until a certain point and decrease afterward. Based on the result (Fig. 3), the trend of TSS removal were up to $140 \mathrm{rpm}$ in most of the time varied. With the higher speed, the colloids more easily destabilized and formed flocs. On the other hand, agitation above $140 \mathrm{rpm}$ would be disturbing the interaction between particles that lead to breakage flocs. Consequently, there would be a limit of agitation speed applied in the mixture that made the flocs would not 
separate again. With the same mechanism, the TDS removal also showed a similar trend (Fig. 4). The highest TDS removal was achieved using $140 \mathrm{rpm}$.

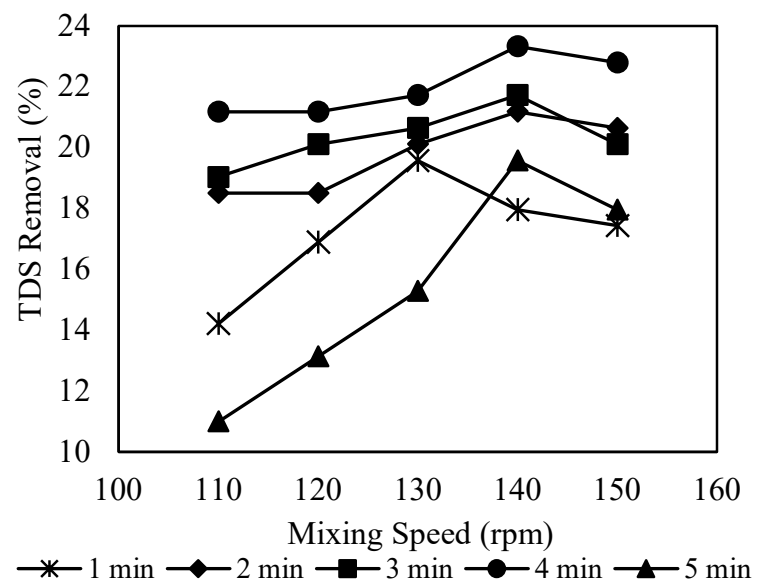

Fig. 4. The effect of mixing speed in chitosan addition for TDS removal

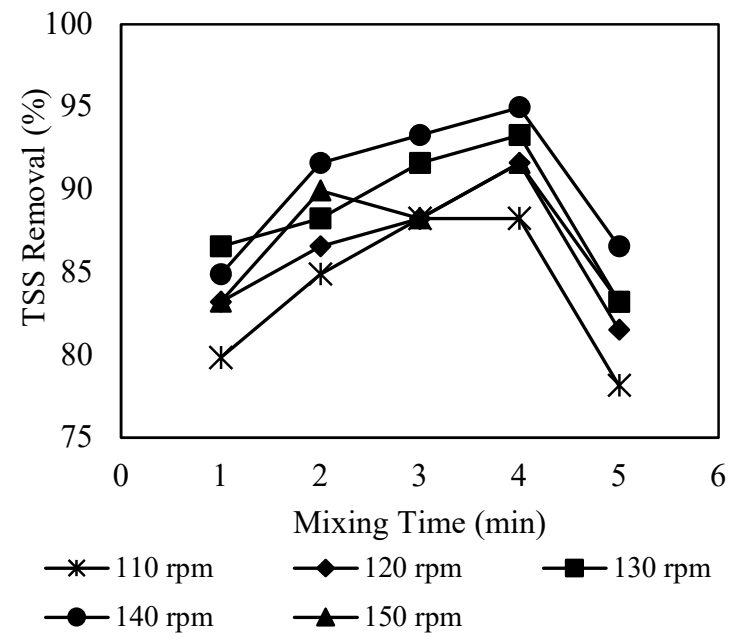

Fig. 5. The effect of mixing time in chitosan addition for TSS removal

The difference in rapid mixing period also affected the solids removal. The process of flocs formation needed time due to the interactions of the colloid particles and coagulant. Based on Fig. 5, the longer period applied in the rapid mixing process would affect the amount of TSS removal. The result indicated that TSS removal in the mixture showed an increasing trend up to 4 minutes but decreased afterward. This condition also happened in the TDS removal (Fig. 6) where the highest removal percentage in 4 minutes mixing. The contact time would lead to the interaction between the positive ions from chitosan and negative ions from the water pollutant to form the flocs. But, when the stirring took longer than 4 minutes, the stability of the flocs would decrease due to the longer exposure to high shear. It will cause a reduction in collision efficiency and breakage of the flocs. This condition was also found in $\mathrm{Yu}$ et al [21] where longer rapid mix time also led to the final flocs size reduction and flocs breakage. So, to result in good performance of solids removal, the operating conditions should set on the optimum conditions. The use 4 minutes in period with 140 rpm agitation, the TSS would be reduced until $94.96 \%$ or from $59.5 \mathrm{mg} / \mathrm{L}$ to $3 \mathrm{mg} / \mathrm{L}$. While for TDS removal up to $23.32 \%$ or from $373 \mathrm{mg} / \mathrm{L}$ to $286 \mathrm{mg} / \mathrm{L}$.

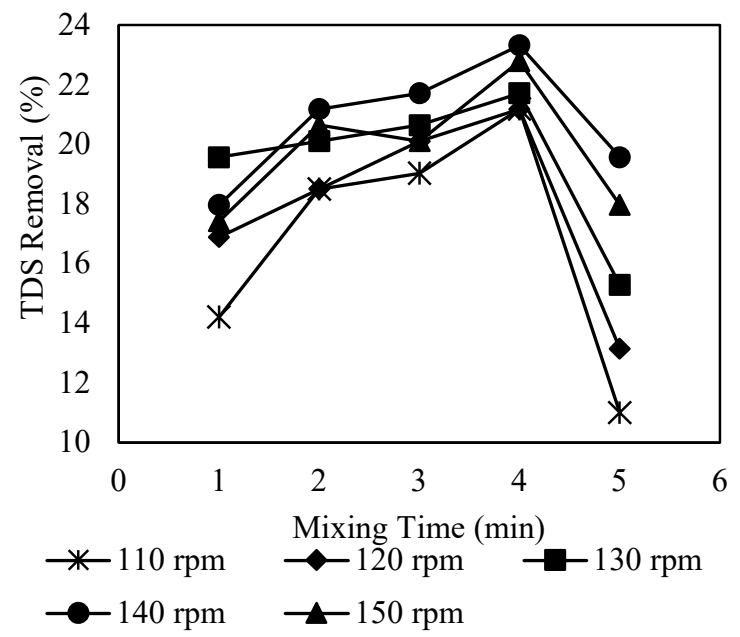

Fig. 6. The effect of mixing time in chitosan addition for TDS removal

\section{Conclusion}

The shell of Corbula faba Hinds contains chitin that can be processed into chitosan. With the deacetylation process, the chitosan deacetylation degree was $65.08 \%$. For the coagulation process, the chitosan used to treat the Jagir River water that has initial condition of TSS as 373.0 $\mathrm{mg} / \mathrm{L}$ and TDS as $59.5 \mathrm{mg} / \mathrm{L}$. Chitosan addition in sample water would destabilize the colloidal pollutant and accelerate the floc formation. The work of the coagulation process is also influenced by the mixing operation condition. The higher mixing speed and time would increase the solids reduction but only up to a point. Optimum conditions were achieved in 4 minutes mixing with $140 \mathrm{rpm}$ of agitation. Using that operation, the TSS removal was up to $94.96 \%$ while the TDS removal was $23.32 \%$.

\section{References}

1. K. T. Pursetyo, W. Tjahjaningsih, and H. Pramono, J. Ilm. Perikan. Dan Kelaut. 7, 31 (2015).

2. S. Prayitno and T. Susanto, Kupang Dan Produk Olahannya (Kanisius, Yogyakarta, 2001).

3. M. Jović, M. Mandić, M. Šljivić-Ivanović, and I. Smičiklas, Stud. Mar. 32, 47 (2019).

4. A. Abdulkarim, M. T. Isa, S. Abdulsalam, A. J. Muhammad, and A. O. Ameh, Civ. Environ. Res. 3, 108 (2013).

5. M. A. Barbosa, A. P. Pêgo, and I. F. Amaral, Compr. Biomater. 221 (2011).

6. T. Jiang, R. James, S. G. Kumbar, and C. T. Laurencin, Chitosan as a Biomaterial: Structure, Properties, and Applications in Tissue Engineering and Drug Delivery, 1st ed. (Elsevier Inc., 2014). 
7. L. Pérez-Álvarez, L. Ruiz-Rubio, and J. L. Vilas-Vilela, J. Chem. Educ. 95, 1022 (2018).

8. F. S. El-banna, M. E. Mahfouz, S. Leporatti, M. ElKemary, and N. A. N. Hanafy, Appl. Sci. 9, 1 (2019).

9. A. L. Ahmad, N. H. Mat Yasin, C. J. C. Derek, and J. K. Lim, Chem. Eng. J. 173, 879 (2011).

10. D. Arfiati, A. M. S. Hertika, D. A. Lukito, and A. W. Puspitasari, IOP Conf. Ser. Earth Environ. Sci. 416, (2020).

11. B. H. Z. Sami, W. Jee khai, B. F. Z. Sami, C. Ming Fai, Y. Essam, A. N. Ahmed, and A. El-Shafie, Ain Shams Eng. J. 12, 1607 (2021).

12. G. Tchobanoglous, F. L. Burton, and H. D. Stensel, Wastewater Engineering: Treatment and Reuse (2003).

13. M. Jamei, I. Ahmadianfar, X. Chu, and Z. M. Yaseen, J. Hydrol. 589, 125335 (2020).

14. O. P. Sahu and P. K. Chaudhari, J. Appl. Sci. Environ. Manag. 17, (2013).

15. H. Altaher, J. Hazard. Mater. 233-234, 97 (2012).

16. R. Bergamasco, C. Bouchard, F. V. da Silva, M. H. M. Reis, and M. R. Fagundes-Klen, Desalination 245, 205 (2009).

17. A. M. Marey, Rev. Bionatura 4, 856 (2019).

18. F. Renault, B. Sancey, P. M. Badot, and G. Crini, Eur. Polym. J. 45, 1337 (2009).

19. M. Rossini, J. G. Garrido, and M. Galluzzo, Water Res. 33, 1817 (1999).

20. W. P. Cheng, F. H. Chi, R. F. Yu, and Y. C. Lee, J. Polym. Environ. 13, 383 (2005).

21. W. zheng Yu, J. Gregory, L. Campos, and G. Li, Chem. Eng. J. 171, 425 (2011). 